\title{
Sustainable Transport in Freiburg: Lessons from Germany's Environmental Capital
}

\author{
Ralph Buehler ${ }^{1}$ and John Pucher ${ }^{2}$ \\ ${ }^{1}$ School of Public and International Affairs, Virginia Tech, Alexandria, \\ Virginia, USA \\ ${ }^{2}$ Bloustein School of Planning and Public Policy, Rutgers University, \\ New Brunswick, New Jersey, USA
}

\begin{abstract}
This article examines changes in transport and land-use policies in Germany over the last 40 years that have encouraged more walking, bicycling and public transport use. It focuses on a case study of policy changes in the city of Freiburg, where over the last three decades, the number of bicycle trips tripled, public transport ridership doubled, and the share of trips by automobile declined from $38 \%$ to $32 \%$. Since 1990, motorization rates have leveled-off and per-capita $\mathrm{CO}_{2}$ emissions from transport have fallen-despite strong economic growth. The analysis identifies policies that are transferable to car-oriented countries around the world.
\end{abstract}

Key Words: climate change, Freiburg, Germany, land-use planning, sustainability, transport policy

\section{INTRODUGTION}

Transport is responsible for about a third of all Greenhouse Gas (GHG) emissions in the USA and one fifth of worldwide GHG emissions, mainly in form of $\mathrm{CO}_{2}$ (International Energy Agency 2006; Sperling and Cannon 2009; U.S. Department of Transportation 2009b). Governments throughout the world have recognized that the reduction of transport related $\mathrm{CO}_{2}$ emissions plays an important part in combating climate change (Banister 2005; European Commission 2009; USDOT 2009b; World Bank 1996). Many studies suggest that growing reliance on the automobile for urban travel is an important reason for increased energy use and $\mathrm{CO}_{2}$ emissions as well as other problems such as traffic congestion, air pollution, and traffic

Address correspondence to Ralph Buehler, Virginia Tech, School of Public and International Affairs, 1021 Prince Street, Suite 200, Alexandria, VA 22314. E-mail: ralphbu@vt.edu 
fatalities (Banister 2005; European Conference of Ministers of Transport 2003; Downs 2004; Hanson and Giuliano 2004; National Highway Traffic Safety Administration 2004; Oak Ridge National Laboratories 2008; Texas Transportation Institute 2009; Transportation Research Board 2009; Vuchic 1999; World Health Organization 2009). By comparison, public transport, bicycling, and walking are generally assumed to be healthier, more energy efficient, and less polluting.

Climate change is only one of many aspects of sustainability. The World Bank, for example, defines sustainability more broadly, including environmental, social, and economic dimensions of sustainability (World Bank 1996). Environmental sustainability conserves natural resources, minimizes pollutants, and mitigates impacts on ecosystems, such as climate change. Social sustainability includes considerations of health and safety, accessibility, and the distribution of benefits and costs among groups of society. Economic sustainability focuses on economic growth, cost effectiveness, and financial viability. Few studies actually consider all these aspects of sustainability, but it is important to note that the concept is far broader than just $\mathrm{CO}_{2}$ emissions.

The automobile accounts for the majority of trips in almost all Organization for Economic Co-operation and Development (OECD) countries, but with considerable variation. The USA, Canada, and Australia are among the most car-dependent nations in the world-with over 80 percent of passenger trips by automobile and light truck, compared to a range of 45 to 70 percent in Western European countries. As shown in Figure 1, countries with a higher share of trips by public transport, walking, and cycling have much lower levels of $\mathrm{CO}_{2}$ emissions from road and

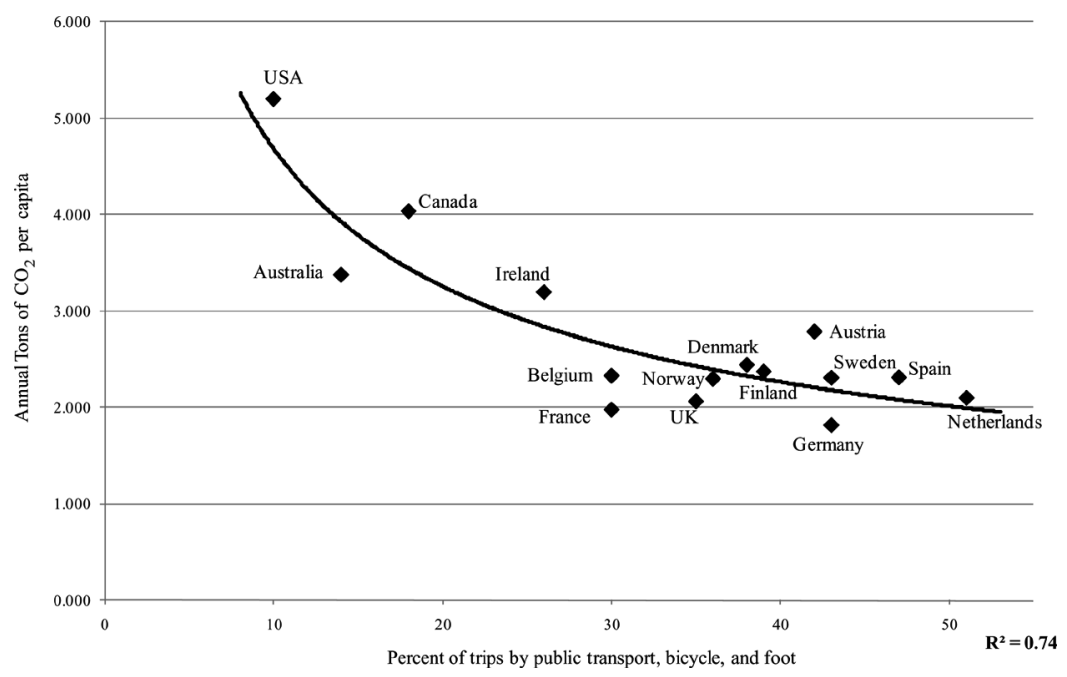

Figure 1. Inverse relationship between share of urban trips by public transport, bicycle, and foot and per capita annual $\mathrm{CO}_{2}$ emissions from road and rail transport in Australia, Canada, the USA and Western European countries, 2000-2008. (Bassett, Pucher, Buehler, Thompson, and Couter 2008; BMVBS 1991-2008; IEA 2009) 


\section{R. Buehler and J. Pucher}

rail fuel consumption. $\mathrm{CO}_{2}$ emissions per capita in Western European countries are less than half as high as in Canada and Australia and less than a third as high as in the USA.

The USA has led the world in motorization since the early 20th Century. Among European countries, however, Germany has the highest motorization rate, the strongest automobile industry, and the most extensive highway network. The USA and Germany have many similarities: high per-capita incomes, almost universal car ownership, and similar economic and political systems. Yet travel behavior in the two countries is very different, with far greater car dependence and more $\mathrm{CO}_{2}$ emissions in the USA. Germans not only drive less, but the German vehicle fleet is also more energy efficient and less polluting. It is the combination of less car use and more advanced technology that accounts for Germany's sustainability edge over the USA. Our analysis of sustainable transport and land use policies in Germany provides useful lessons not only for the USA but also for other cardependent countries—such as Australia and Canada-seeking to improve the sustainability of their transport systems.

Germany's transport, land use, housing, and taxation policies at all government levels have increasingly promoted sustainability since the 1970s. The German federal government has provided the framework for more sustainable transport, but cities and states have played a crucial role in developing and implementing innovative policies.

The southwestern city of Freiburg has been Germany's leader in sustainable transport and land-use. Many policies pioneered in Freiburg have spread to other cities in Germany and worldwide. Today, Freiburg is considered Germany's 'environmental capital' and its most sustainable city. Over the last three decades, Freiburg's coordinated transport and land-use policies have tripled the number of trips by bicycle, doubled transit ridership, and reduced the share of trips by car from $38 \%$ to $32 \%$. Since the early 1990 s, the level of motorization has leveled off, and per-capita $\mathrm{CO}_{2}$ emissions from transport have fallen, in spite of strong economic and population growth. Those are impressive accomplishments in a country such as Germany with a powerful car industry, influential car lobbies, and a love affair with the car perhaps even more passionate than in the USA, Canada, and Australia.

This article first compares the overall sustainability of the American and German urban passenger transport systems. Next it identifies key sustainable transport and land-use policies implemented at the federal level in Germany over the last 40 years. We then turn to a detailed case study of the city of Freiburg. The paper concludes with lessons from Freiburg for other cities.

\section{TRENDS IN SUSTAINABLE TRANSPORT IN GERMANY AND THE USA}

Germany and the USA are both affluent western countries with extensive limited access highway networks, high levels of motorization, and important automobile industries and lobbies. In both countries, car ownership has grown rapidly since the Second World War. In 2006, Germans owned 30\% fewer cars per capita than Americans (560 vs. 780 cars and light trucks per 1,000 inhabitants), and Germans drove less than half as many kilometers by car $(11,500 \mathrm{~km}$ vs. $24,000 \mathrm{~km}$ per capita; 


\section{Sustainable Transport in Freiburg, Germany}

BMVBS 1991-2008; Federal Highway Administration 1990-2008, 2006). In Germany, public transport, walking and cycling accounted for $40 \%$ of all trips compared to roughly 10\% in the USA (Bundeministerium für Verkehr, Bau und Stadtentwicklung (BMVBS) 2004; Oak Ridge National Laboratory (ORNL) 2005). Americans drove for $70 \%$ of trips shorter than $1.6 \mathrm{~km}$-compared to only 27\% in Germany (BMVBS 2004; ORNL 2005).

Available data suggest that American reliance on the automobile for almost all trips results in a less environmentally sustainable transport system. In 2006, personal transport energy use and $\mathrm{CO}_{2}$ emissions per capita were only about a third as high in Germany as in the USA (18,000 vs. 58,000 MJ per year and 1,300 vs. $3,900 \mathrm{~kg}$ of $\mathrm{CO}_{2}$ emissions). The trend is also more favorable in Germany. From 1999 to 2006, per-capita energy use for personal travel in Germany fell by 8\% and per-capita $\mathrm{CO}_{2}$ emissions from transport declined by $7 \%$-compared to increases of $4 \%$ and $2 \%$ in the USA (BMVBS 1991-2008; Department of Energy 2007; FHWA 2006; IEA 2006; ORNL 2008; umwelt bundesamt (UBA) 2005a).

Economic sustainability also appears to be higher in Germany. In 2003, American households spent an average of $\$ 2,712$ more per year on transport than Germans-and a larger share of disposable income (19\% vs. 14\%; Deutsches Statistisches Bundesamt (DESTATIS) 2003; U.S. Department of Labor 2003). Per-capita government spending on transport in Germany is also less. In 2006, for example, total government expenditures for roads and public transport by all levels of government amounted to $\$ 625$ per capita in the USA compared to $\$ 460$ per capita in Germany. Government subsidies accounted for only $30 \%$ of public transport operating budgets in Germany compared to almost $70 \%$ in the USA (American Public Transport Association 2006; Verband Deutscher Verkehrsunternehmen (VDV) 2008).

Social sustainability may also be higher in Germany. In 2006, for example, traffic fatalities per capita were 2.3 times higher in the USA than in Germany. For pedestrians and cyclists the traffic fatality rate per kilometer walked and cycled in Germany is only a third as high as in the USA (International Road Traffic and Accident Database (IRTAD) 2008). Moreover, most destinations in German cities are accessible by some combination of walking, cycling, and public transport, thus offering disadvantaged residents mobility even without cars (BMVBS 2004; Pucher 1998). In contrast, most American cities, and especially their suburbs, are so car-dependent that households without automobile suffer from low mobility and lack access to important destinations (Altshuler, Womack, and Pucher 1979; Deka 2004; Harvey 1973; Schaefer and Sclar 1980).

These comparisons between the two countries are only meant to be indicative, but they suggest that the German transport system is more sustainable along all three dimensions. As in the USA, the German federal government sets the policy framework, while lower levels of government-especially municipalities-develop and implement plans and programs. The Brookings Institution previously published our detailed comparison of federal transportation and land-use policies in Germany and the USA (Buehler, Pucher, and Kunert 2009). Here we briefly summarize key differences in federal policies between the two countries, so that the reader can gain an understanding of the institutional and policy context in Germany. 


\section{R. Buehler and J. Pucher}

\section{FEDERAL POLICIES THAT ENCOURAGE MORE SUSTAINABLE TRANSPORT IN GERMANY}

In Germany, the federal government encourages more sustainable transport through a series of policies and programs. Federal taxes and regulation make car use more expensive and thus encourage the production and purchase of less polluting vehicles. At the same time, the federal government provides dedicated funding and subsidies for public transport investments. Certain federal transport funds are flexible and can be used for walking and cycling infrastructure that increases the safety and convenience of non-motorized modes. Federal regulations also guide the land-use planning process by requiring cooperation among all levels of government and discouraging suburban sprawl. Finally, the federal government provides strategic leadership and integration of transport and land-use policies on and across all levels of government, starting at the federal level with the consolidated Federal Ministry of Transport, Building and Urban Affairs.

\subsection{Federal Transport Policies}

German federal government taxes and regulations make car ownership and use more expensive than in the USA: sales taxes on automobiles are three times higher, and gasoline taxes are nine times higher (Buehler et al. 2009; International Energy Agency (IEA) 2008). The difference in gasoline price at the pump increased significantly from 1999 through 2003 due to an environmental tax, which incrementally raised the gasoline tax in Germany by the equivalent of $70 \varnothing$ per gallon (U.S.) over 5 years (UBA 2005b). Strict EU vehicle regulations, high gasoline taxes, and vehicle-registration fees favor less polluting cars and encourage more fuel efficient vehicles. In 2005, the average fuel economy of German cars and light trucks was $50 \%$ higher than in the USA: $30 \mathrm{mpg}$ vs. $20 \mathrm{mpg}$ (BMVBS 1991-2008; Bureau of Transportation Statistics 2006; FHWA 2006).

Revenues from gasoline taxes and vehicle registration fees in Germany have covered an increasing share of federal, state and local government expenditures on road construction and maintenance-rising from $92 \%$ in 1975 to $259 \%$ in 2006 compared to a history of net subsidies for roadways in the USA (BMVBS 1991-2008; FHWA 1990-2008). In contrast to the USA, the German federal government did not permit limited access highways to penetrate cities (Pucher and Kurth 1995; Transportation Research Board (TRB) 1998). The lack of high-speed freeways in urban areas, combined with widespread traffic calming of residential neighborhoods, might help explain why the average speed of car travel in Germany is $25 \%$ slower than in the USA (BMVBS 2004; Buehler et al. 2009; ORNL 2005).

German state and federal governments jointly develop the Federal Transport Plan, which delineates the federal transport strategy. Until the early 1970s, this plan primarily focused on automobile travel. Since 1973, however, the plan has included societal goals, such as combating traffic fatalities, reducing transport energy use, limiting vehicle emissions, and preserving open space (Koeberlein 1997).

Since the mid-1970s, the federal government has encouraged the coordination of transport planning across modes and jurisdictional boundaries. For example, the German federal government has provided dedicated matching funds to state and local governments for public transport capital investments-if projects are 
part of local comprehensive transport plans, comply with land-use plans, and address the needs of the disabled and the elderly (BMVBS 2005a; Bundesregierung 1999; Rönnau 2004; Rönnau, Schallaböck, Wolf, and Hüsing 2002).

The German federal government only plays a minor role in promoting walking and cycling-mainly limited to federal traffic laws protecting cyclists and pedestrians and making their safety an integral part of the German driver's license test. Most innovations, such as car-free pedestrian zones and integrated city-wide bicycling networks were pioneered and then widely implemented at the local level. The federal government supported these efforts with technical guidance and flexible funding mechanisms, which allowed municipalities to divert highway funds towards non-motorized modes.

\subsection{Federal Regulation of Land-Use Planning}

In Germany, federal, state, regional, and local governments interact in a bottom-up and top-down land-use planning process, which is organized around cooperation and mediation (BMVBS, 2000). In general, lower levels of government participate in the preparation of plans at the next higher level of land-use planning. For example, municipalities contribute to plans at the regional level, regional representatives provide input into state plans, and state officials are represented at the federal level. Once plans are made, lower levels of government are bound by the regulations, goals, and objectives outlined in that plan. The lower the level of government, the more detailed the content of the plan.

Federal involvement in spatial planning is limited to defining the legal framework for planning, ensuring consistency of planning techniques, and-in collaboration with the states-setting broad strategic goals for spatial development, such as sustainability (Wiegandt 2004). Moreover, the federal government regularly publishes a report outlining trends, challenges, and projections for spatial development in Germany (BMVBS 2005b).

Municipal governments draw up the actual land-use plans and decide where different uses are to be built. Local plans in Germany, however, are restricted by regional and state plans and must be in compliance with federal land use, transport, and environmental laws (BMVBS 1993; Fuerst and Scholles 2003; Kunzmann 2001). At each level of government land-use planning is explicitly coordinated with housing, transport, and environmental plans and neighboring jurisdictions are mandated to seek input from each other, requiring states, regions and municipalities to collaborate with their peers (BMVBS 1993, 2000).

The right to develop property is highly circumscribed in Germany. New development is limited by law to areas immediately adjacent to already built-up areasthough exceptions are made on a case by case basis (BMVBS 1993, 2000). Even in the case of private land, developers and the municipality must convince higher levels of government to permit development of areas not adjacent to already existing settlements. Land-owners cannot seek compensation if development rights are not granted (Hirt 2007; Levine 2006; Wiegandt 2004).

Federal policies set the framework, but most policies that make transport more sustainable were developed and implemented on the local level. The German city of Freiburg has been a leader in innovative policies that later spread throughout Germany. 


\section{R. Buehler and J. Pucher}

\section{SUSTAINABLE TRANSPORT IN FREIBURG}

Freiburg has 220,000 inhabitants and is the economic, cultural, and political center of the Black Forest region in southwestern Germany. The region has a population of 615,000 and is less than an hour's travel from Switzerland and France (Gutzmer 2006). Freiburg's economy is based on tourism, university teaching and research, government and church administration, and a broad range of services provided to the surrounding region (City of Freiburg 2009b).

From 1950 to 1970, motorization grew rapidly in Freiburg and was higher than for West Germany as a whole. After the policy reversal in the early 1970s, the automobile ownership rate in Freiburg grew slower than the German average. As shown in Figure 2, the motorization rate did not increase at all between 1990 and 2006, remaining at 420 cars per 1,000 inhabitants - 23\% below the German average in 2006 (City of Freiburg 2008c). While motorization levels stagnated, car use decreased. Between 1982 and 2007, the car share of trips in Freiburg fell from $38 \%$ to $32 \%$ during a period in which the car's mode share was increasing rapidly almost everywhere else in the world (Bratzel 1999; City of Freiburg 2008f; University of Dortmund 2001). At the same time, the bike share of trips in Freiburg almost doubled, from $15 \%$ to $27 \%$, and public transport's share of trips rose from $11 \%$ to $18 \%$ (see Figure 3 ).

Freiburg's combined $68 \%$ share of trips by public transport, bicycling, and walking is higher than in most other cities of similar size: 2 to 10 times higher than in North American cities and 10\% to 30\% higher than in other German cities (Figure 4$)$. The nearby Swiss cities of Bern $(69 \%)$ and Basel $(73 \%)$ have slightly higher "green mode" shares than Freiburg. In some respects, those Swiss cities

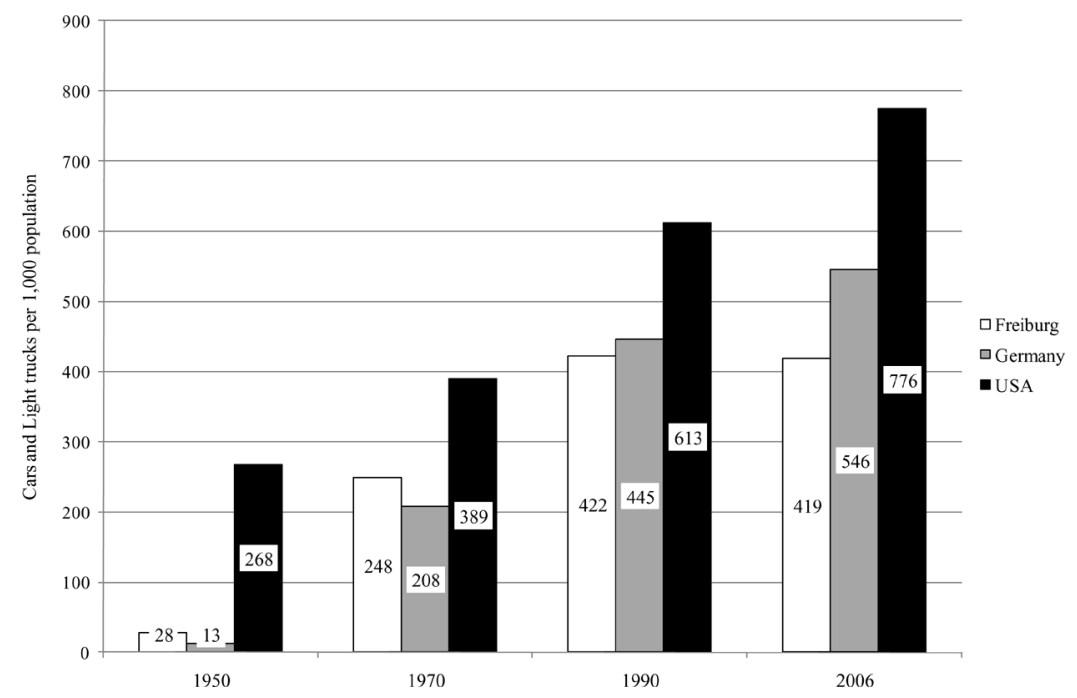

Figure 2. Trend in cars and light trucks per 1,000 population in Freiburg, Germany, and the USA, 1950-2006. (BMVBS 1991-2008; City of Freiburg 2009b, FHWA 1990-2008) 


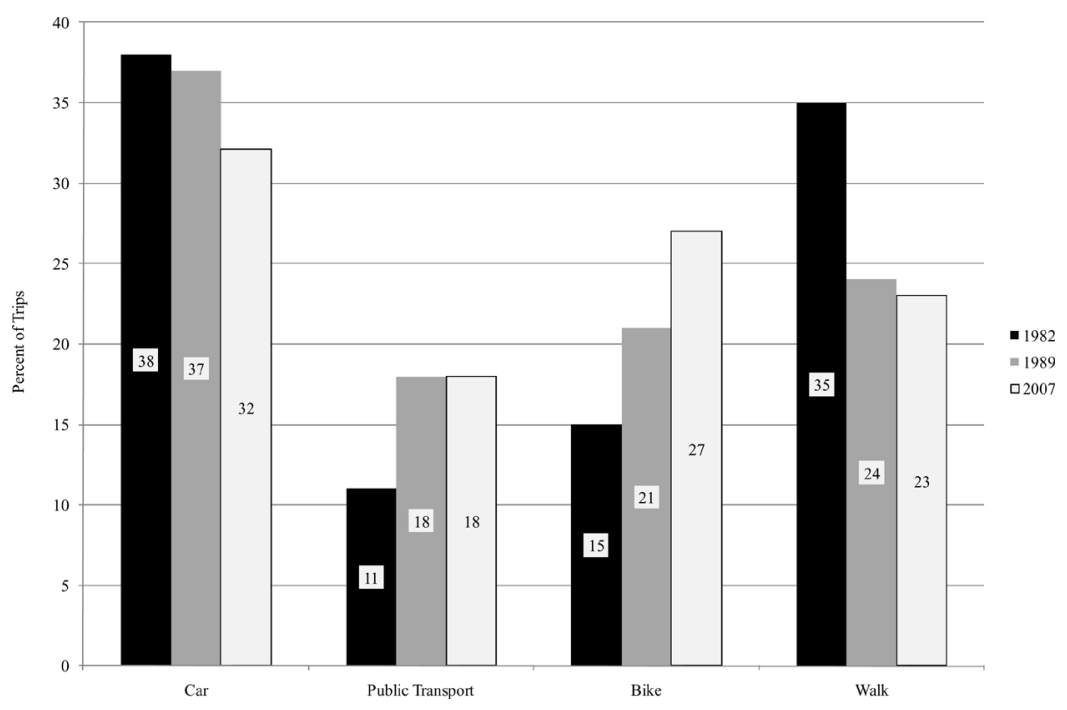

Figure 3. Trend in percent of trips by car, public transport, bicycle, and foot in Freiburg, 1982-2007. (City of Freiburg 2007c; University of Dortmund 2001)

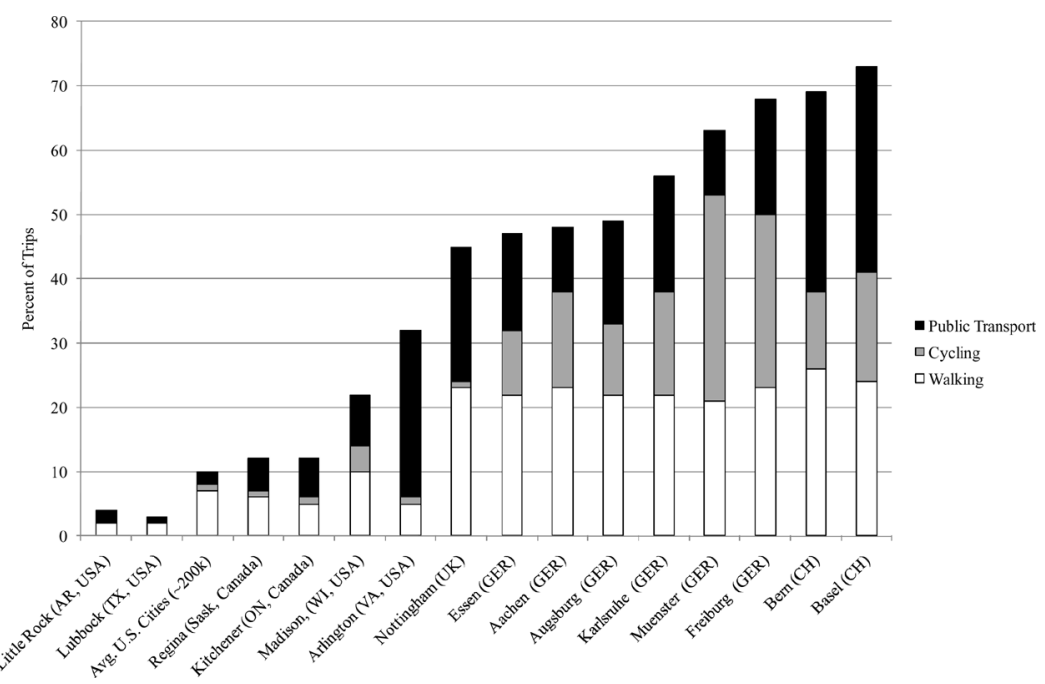

Figure 4. Share of trips by public transport, cycling, and walking in Freiburg and cities of comparable population size $(\sim 200,000)$ in Europe and North America, 2006/2007. (City of Freiburg 2007c; Gutzmer 2006, Socialdata 2009; Statcan 2009; U.S. Census Bureau 2009) 


\section{R. Buehler and J. Pucher}

provided useful models to follow, since they introduced environmental tickets, transit-first traffic priority, and other innovative measures a few years before Freiburg (Bratzel 1999).

Available statistics suggest that Freiburg's transport system has become more sustainable over time. Vehicle $\mathrm{km}$ of car use per capita in Freiburg declined by $7 \%$ on all roads and by 13\% on residential roads from 1990 to 2006 (City of Freiburg 2007a; Oeko Institut 2007; State of Baden Wuerttemberg 2008). From 1992 to 2005, transport $\mathrm{CO}_{2}$ emissions per capita in Freiburg fell by $13.4 \%$ to a level that is $89 \%$ of the German average and only $29 \%$ of the American average (City of Freiburg 2005; Oeko Institut 2007; UBA 2005a, 2008). Travel is also safer in Freiburg than in Germany as a whole: 3.7 traffic fatalities per 100,000 inhabitants vs. 6.5 in Germany and 14.7 in the USA (Indikatoren, Karten und Graphiken zur Raum- und Stadtentwicklung (INKAR) 2005; National Highway Traffic Safety Administration (NHTSA) 2004; Polizeidirektion Freiburg 2005). Moreover, social equity is high since all parts of the city are easily accessible by public transport, cycling, and walking. Finally, the financial viability of public transport is relatively high in Freiburg, requiring only $10 \%$ of its operating costs to be subsidized through government funds, compared to $30 \%$ for Germany as a whole and $70 \%$ in the USA (APTA 2006; Regio Verbund Gesellscahft 2008c; VDV 2008).

The trends away from car use and toward more sustainability in Freiburg occurred in spite of strong population growth, rising incomes, and a booming economy. From 1990 to 2007, Freiburg's population increased six times faster than the German average (17\% vs. less than 3\%). Employment in Freiburg grew at three times the overall German rate from 1996 to 2005 (11\% vs. 4\%; INKAR 2005). In 2005, per-capita income in Freiburg was 29\% higher than for Germany as a whole (€35,200 vs. €27,200). Freiburg's economy has profited from its increasing focus on sustainability. Since the early 1980s, Freiburg has fostered the development of its environmental, solar, and biotechnology industries. By 2007 Freiburg had become Germany's leader in green industries, with 1,500 companies employing roughly 10,000 people and contributing approximately $€ 500$ million to the local economy annually (City of Freiburg 2009a).

Economic success and widespread political support for sustainability made changes in Freiburg's transport and land-use policies possible. Since the 1970s, the city has increasingly restricted car use while improving public transport, cycling, and walking. That combined carrot-and-stick approach has been crucial to generating public and political support for sustainable transport. Perhaps most important, car restrictive measures are not viewed as punitive, since car users are offered safe, convenient, and affordable alternatives.

\subsection{Integrating Transport and Land-Use Planning in Freiburg}

Freiburg's old town was almost completely destroyed in bombing raids during the Second World War. That was the beginning of Freiburg's remarkable history of transport and land-use planning (see Table 1). In 1948, Freiburg's city administration decided to rebuild the city center in its historic compact form. Most of Freiburg's post-war population growth, however, was accommodated in new settlements at the fringe of the existing city (Pucher and Clorer 1992). Indeed, similar to many American cities, Freiburg's land-use plan of 1955 endorsed geographic expansion 
Table 1. Timeline of important events in Freiburg's transport and land-use policy from 1945-2009.

\section{Rebuilding the City to Serve the Needs of the Car}

1944: Over $80 \%$ of Freiburg is destroyed in an air bombing raid

1948: Reconstruction Plan - specifies that the old town be rebuilt in its compact pre WWII form

1955: First Land Use Plan - focuses on growth and geographic expansion

1961: Streetcar line Haslach-Herdern abandoned

1963-1971: Second Land Use Plan was prepared - focuses on growth and geographic expansion (never implemented)

1969: First Transport Plan (Generalverkehrsplan) - focuses on accommodating car use, but also recommends to preserve and potentially expand the streetcar system

\section{Crucial Decisions : Laying the Ground Work for Sustainable transport}

1970: First Bike Network Plan

1972: $29 \mathrm{~km}$ of unconnected cycling paths and lanes in the city

1972: City Council decides to expand the light rail network (referred to as "Stadtbahn")

1973: City Center converted into a pedestrian only zone. This was the largest pedestrian zone in Germany at the time

1978: Construction of first light rail extension begins

1979: Second Transport Plan (Generalverkehrsplan) emphasizes "changed" political and environmental circumstances, the connection of transport and land use, and favors the so-called "green modes" (walking, cycling, and transport) over the car

\section{Improving Public Transport, Walking, and Cycling}

1981: New Land Use Plan-centers new development around public transport stops

1983: First new light rail line begins operation

1984: Introduction of Germany's first transferable flat-rate monthly transport ticket: the so-called "environmental ticket"

1984: City of Freiburg and adjacent counties begin cooperation on public transport policy and funding

1985: Transport providers in Freiburg and surrounding counties begin collaboration for transport planning

1985: City council decides to continue expansion of public transport system

1985/1986: Two new light rail lines/extensions start operating

1987: City council decides to traffic-calm all neighborhood streets to $30 \mathrm{~km} / \mathrm{h}$ by 1991

1987: 2,200 bike parking spots in the City

1989: Transport Plan Reauthorization (Gesamtverkehrskonzeption) with explicit goal to reduce and restrict car use and to prioritize green modes

Restricting Car Use and Further Promoting the Green Modes

1991: Geographic extension of flat rate monthly ticket to include surrounding counties (Regio-Umwelt-Karte)

1993-2006: Vauban neighborhood redeveloped around public transport with car free neighborhood streets

1994-2010: New Rieselfeld neighborhood developed around public transport

1994: Regional Transport Authorities founded (Regio Verbund, RVF, and ZRF) - replace less formal regional collaboration of public transport planning agencies and operators from 1980s

1996: First regional public transport plan completed 


\section{R. Buehler and J. Pucher}

Table 1. Continued.

1996: Regional rail service "Breisgau S-Bahn 2005" begins operation

1997-2008: Three new light rail lines and four regional rail lines (Breisgau S-Bahn) begin operation

1999: Land Use Plan with broad citizen participation - citizen's demanded more mixed use and dense development than the city administration had proposed

2007: $410 \mathrm{~km}$ of bike paths and lanes in the city; plus two kilometers of bicycle only streets

2008: Land Use Plan focuses on high density development along transport routes, sustaining local neighborhood centers, and mix of uses; this plan was closely coordinated with the 2008 Transport Plan

2008: Transport Plan with three main goals: (1) shifting car trips to green modes, (2) making necessary/unavoidable car trips more sustainable, (3) local accessibility with short trip distances

2008: $90 \%$ of residents live in traffic calmed areas of $30 \mathrm{~km} / \mathrm{h}$ and slower; there are 177 home zones with speed limits of $7 \mathrm{~km} / \mathrm{h}$

2009: 6,040 bike parking spots in the city

2009: Four new light rail lines/extensions planned

of the city, based on automobile transport. During this period, old streetcar lines were abandoned and service was cut back, since buses and the automobile were deemed the modes of transport of the future (Nahverkehr Breisgau 2008). Land-use plans gave priority to new greenfield developments with wide streets and ample car parking. Even the old town was adapted to the automobile-with new parking lots on historic squares and a direct highway connection from downtown to the Autobahn. During this time, car ownership and use increased, and so did air pollution, traffic fatalities, and traffic congestion (Gutzmer 2006; Pucher and Clorer 1992).

Freiburg's second auto oriented land-use plan of the 1960s was never approved by the city council and got shelved in the early 1970s after long controversial discussions between the public, council members, and the administration (City of Freiburg 2008b). By then, public opinion had shifted away from supporting automobile centered growth-due to various environmental and social problems caused by the car and the oil crisis of 1973 .

Moreover, during the early 1970s, the planned construction of a nuclear power plant just $30 \mathrm{~km}$ from Freiburg's old town made environmental protection a critical issue (Hopwood 2007). Protests against the state government's plan to build the nuclear power plant lasted for years and forged an unlikely alliance of leftist students, Catholic and Protestant church leaders, the conservative party, and local farmers. Highly respected civic leaders were at the center of the local opposition to the state government's plan. Their role in the protests legitimized environmental protection and alternative development ideas for the local population (Chaney 2008; Hopwood 2007). Over the last 40 years Freiburg has developed a strong tradition of cooperation, negotiation, and consensus among city administration, citizen groups, and local businesses (Bratzel 1999). Public discourse, citizen participation, and cooperation paved the way for a gradual change towards sustainability in Freiburg (Bratzel 1999).

Freiburg's first integrated transport plan of 1969 had inadvertently laid the foundation for the changes to come. Although still focusing on car use, the plan 


\section{Sustainable Transport in Freiburg, Germany}

recommended preserving and potentially expanding the streetcar network-a suggestion the city council followed in 1972. The early 1970s also saw Freiburg's first integrated bicycling network plan and a new car-free pedestrian zone in the center of old town-the largest pedestrian zone in all of Germany at the time, as illustrated in Figure 5 (Beatley 2000). Citizen groups had successfully lobbied
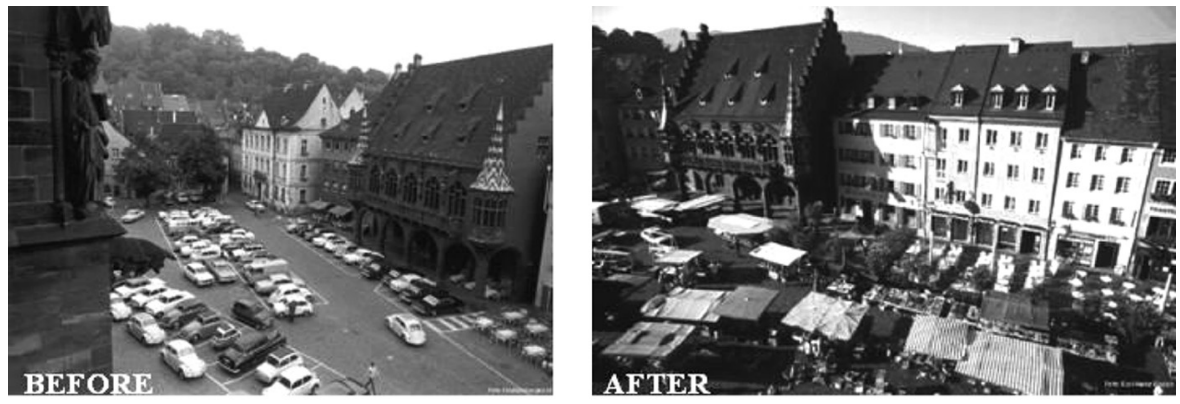

A. Freiburg's Cathedral Square was used as a car park in the 1960 s (above left). During the mid-1970s cars were banned. It is now a lively pedestrian zone with an open air market (above right).
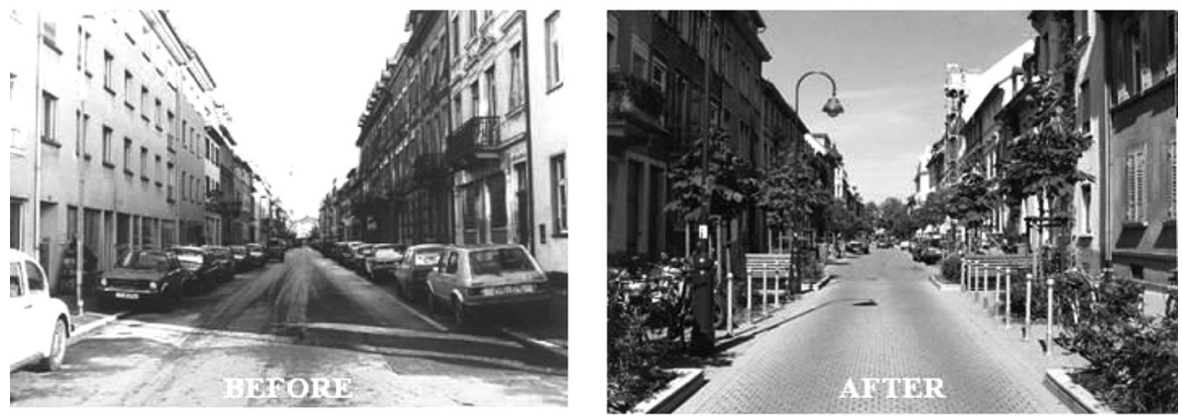

B. Klarastrasse was a street designed for cars, in the 1960 s (above left). Since traffic calming in the late 1980 s, car traffic has dropped and it is now a safe and quiet neighborhood street (above right).

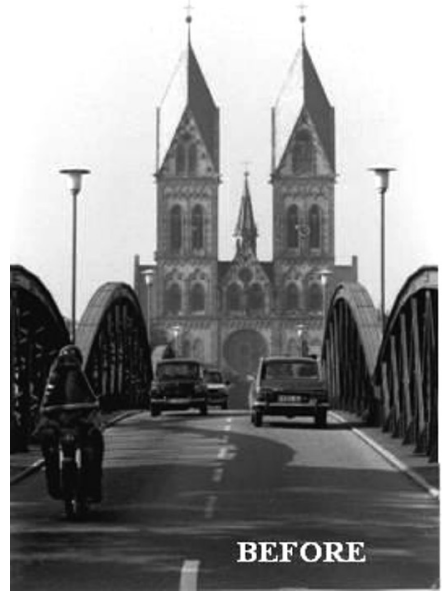

C. The Wiwili Bridge in Freiburg ca. 1970 (left): Both lanes were reserved for motor vehicles. The former tram line crossing this bridge was removed in the $1960 \mathrm{~s}$. In the $1990 \mathrm{~s}$ the bridge was closed for cars and is now used exclusively by bicycles (right).

Photos provided by the City of Freiburg and Karl-Heinz Raach, Freiburg

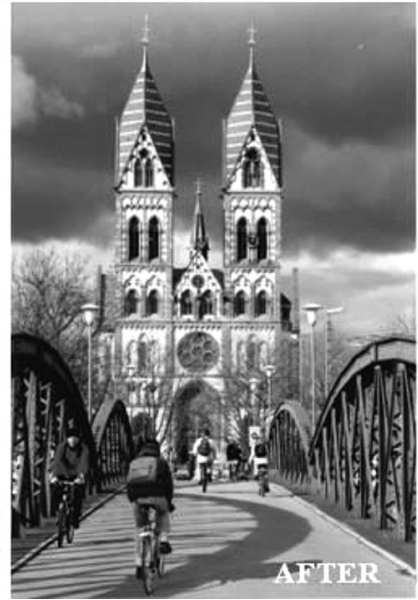

Figure 5. Policy changes in the 1970s have restricted car use in Freiburg and increased accessibility by non-motorized modes and the quality of life. 


\section{R. Buehler and J. Pucher}

the city administration to restrict car access to downtown-while local business owners opposed this idea. Jointly, the city administration, citizen groups, and local businesses reached a consensus of banning cars from downtown and providing automobile parking garages along a ring road at the fringes of the car-free zone (Bratzel 1999). Many of the fragmented policies implemented in the 1970s were formalized into official transport and land-use plans in the late 1970s.

In 1979, Freiburg's second integrated transport plan focused on environmental protection and sustainable development. The new plan favored public transport, walking, and cycling over the automobile and called for the integration of transport and land-use planning. Priorities for land-use policies shifted accordingly. The land-use plan of 1981 prescribed that new development was to be concentrated along public transport corridors, especially the city's expanding light rail system, whose first new line opened in 1983 (Blatter 1995; City of Freiburg 2008b; Hilliard 2006).

During the 1980s, the city council—encouraged by neighborhood associationsvoted to traffic-calm all residential neighborhoods to $30 \mathrm{~km} / \mathrm{hr}$ and to discourage through traffic in residential areas (Blatter 1995). The cost of driving was further increased by parking management schemes which limited long-term parking and charged motorists higher parking fees (Blatter 1995). The re-authorization of Freiburg's transport plan in 1989 re-emphasized the explicit goal of limiting car travel and increasing use of the green modes-walking, cycling and public transport (City of Freiburg 2007c).

From 1993 to 2009, Freiburg redeveloped two inner suburban neighborhoods around newly extended light rail lines (City of Freiburg 2007b, 2008e, 2009a; Ryan and Thorgmorton 2003). Rieselfeld was built on the site of a former sewage farm; Vauban was built on the grounds of an abandoned French military base. Both districts sharply limit car access and parking. All streets are traffic calmed at $30 \mathrm{~km} / \mathrm{hr}$ or less. Many neighborhood roads are designated as so-called home zones-streets with speed limits set at $7 \mathrm{~km} / \mathrm{hr}$ and traffic priority for pedestrians, cyclists, and playing children (see Figure 6). Both communities are compactly laid out and mix residential, commercial, educational, religious, and recreational land uses. They provide a wide range of housing types for low-income as well as affluent households and specifically favor inclusion of women, families, the elderly, and persons with disabilities. Rieselfeld and Vauban feature attractive green spaces, low energy construction methods, solar energy, and rain water re-use (City of Freiburg 2007b, 2008e; Ryan and Thorgmorton 2003).

Vauban is an example of Freiburg's grass roots citizen involvement in planning for land-use and transport. In the early 1990s, the city administration had plans to redevelop Vauban into a family friendly neighborhood. This new settlement for 5,000 inhabitants was designed to attract young families and discourage them from moving to the suburbs (City of Freiburg 2008e). In 1993, residents of Vauban founded the not-for-profit-organization Forum Vauban, which worked together with the city administration to use sustainable low-energy construction methods, mix land uses, preserve old trees, and make large parts of the new development car-free (Forum Vauban 2009). They had to overcome some major obstacles.

Similar to most local American zoning codes, the state of Baden Wuerttemberg requires minimum parking standards for new developments (Forum Vauban 2009; Gutzmer 2006). After long negotiations, Vauban was granted a waiver for minimum 


\section{Sustainable Transport in Freiburg, Germany}
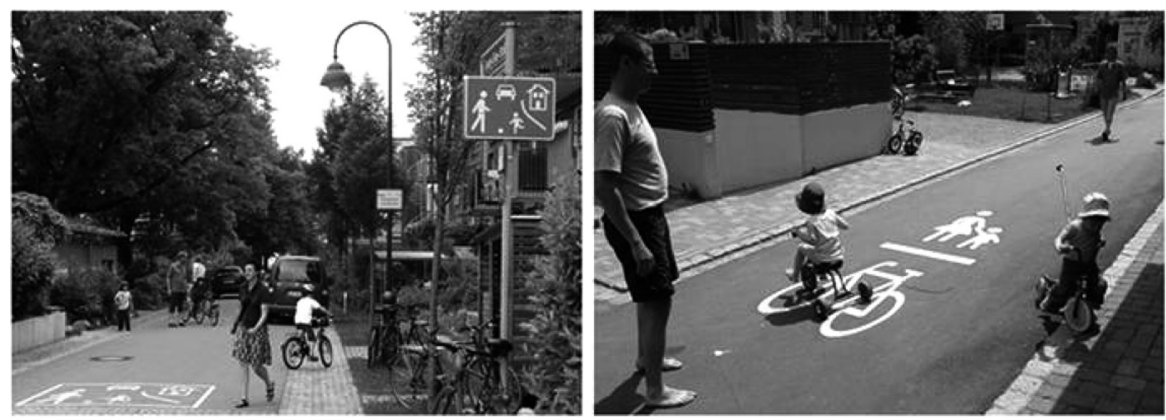

Freiburg's Vauban neighborhood attracted many young families. Children and adults claim the streets in Vauban's home zones (above left) or on one of Vauban's car-free streets (above right).
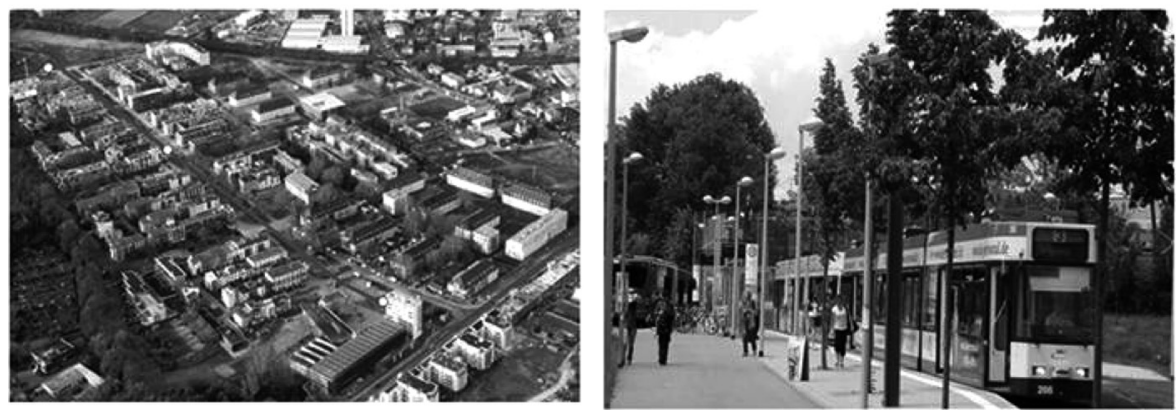

A light rail line runs through the center of Vauban (blue line above left). Light rail and bus service are easily accessible by foot and by bicycle (above right).

Photos provided by Peter Berkeley and the City of Freiburg

Figure 6. Car-free living in Freiburg's Vauban neighborhood and a high quality of life attracted many young families.

parking requirements provided that enough green space was preserved for potential future construction of parking lots. Building permits in Vauban are issued for residential units without parking spots. Residents who decide to own a car can purchase a parking spot in one of the parking garages at the edge of the development for the equivalent of $\$ 25,000$. Residents who wish to live car-free simply pay a one-time fee of $\$ 5,000$ to preserve open space at the edge of the developmentin lieu of a parking spot. This arrangement has proven successful. A recent survey showed that there are 150 cars per 1,000 inhabitants in Vauban, compared to roughly 420 for the City of Freiburg and over 560 for Germany (Forum Vauban 2009).

Most daily shopping trips of Vauban residents are by walking or cycling and occur within the neighborhood itself (Forum Vauban 2009). But there are good travel options to destinations in other parts of the city and region. Vauban is well connected to Freiburg's extensive bicycling network. In 2006, a new light rail line was completed down Vauban's main street. It provides a direct connection to the center of Freiburg in less than 15 minutes, with trains running every ten minutes. The Vauban line connects with numerous other light rail and suburban rail lines that provide access to the entire region. Vauban also offers a car sharing program for residents needing to make an occasional trip by automobile (Forum Vauban 2009). 


\section{R. Buehler and J. Pucher}

Freiburg's most recent land-use and transport plans of 2008 were developed simultaneously and are fully integrated. Both reiterate the earlier goals of reducing car use, but they are more explicit about prohibiting car-dependent developments and actively support car-free neighborhoods. The plans focus on compact development along light rail routes, strengthening local neighborhood commercial and service centers, and mixing housing with stores, restaurants, offices, schools, and other non-residential land uses (City of Freiburg 2008b). Central development is explicitly favored over peripheral development on the suburban fringe. The city has banned all car-dependent big-box retailers such as home improvement stores, furniture stores, and garden centers, not only because of the car traffic they generate but also because they draw customers away from central city and neighborhood retailers. Moreover, the new land-use plan identifies 30 priority locations for small retail businesses in Freiburg's neighborhood centers, with the goal of keeping trip distances short and assuring local accessibility on foot and by bicycle (City of Freiburg 2004).

The city coordinated its plans with 19 neighboring municipalities and 12 special purpose governments in the region. Moreover, the plans were developed with extensive citizen participation at every stage and reflect widespread support for environmental protection. In fact, Freiburg's citizen groups considered the city administration's initial draft of the land-use plan too car-oriented and the planned development densities too low. In a second round the city and 900 citizens jointly developed land-use strategies and goals and developed a new draft of the land-use plan. This plan focused on higher density and more mixed-use infill development, had broad citizen support, and was finally approved by the city council (City of Freiburg 2004).

Through the political process, Freiburgers have consistently supported restrictions on the overall amount of land available for development outside of already built-up areas. In the Freiburg region, as in most other German regions, large areas of land in and near the city have been explicitly zoned for agriculture (many vineyards and fruit orchards), forest preserves, wildlife sanctuaries, or simply as undeveloped open space. Freiburgers value these undeveloped 'green corridors' throughout the city as important destinations for everyday recreational activities. As documented in the following sections, the complete turnaround in Freiburg's transport policies in the 1970 s resulted in dramatic improvements for public transport, bicycling, and walking, while making car use more expensive, slower, and less convenient.

\subsection{Improvements in Public Transport}

After two decades of cutting streetcar services in the 1950s and 1960s, only 14 kilometers of old streetcar lines were still in operation in Freiburg in 1970 (Nahverkehr Breisgau 2008; Schroeder 2009). Service was slow, infrequent and outdated-and Freiburg's public transport ridership had been continuously declining. Expanding and upgrading the light rail system was at the center of Freiburg's multi-faceted strategy to integrate public transport and land-use planning. Since the opening of the first new light rail line in 1983, Freiburg has added four new lines with a total extent of $36.4 \mathrm{~km}$ in 2008 (City of Freiburg 2009b). During the same period, the supply of light rail service almost tripled (from 1.1 to 3.2 million vehicle $\mathrm{km}$ ). In 2006, $65 \%$ of Freiburg's residents and $70 \%$ of all jobs were located within easy walking distance (300 meters) from a light rail stop (City of Freiburg 2008f). 


\section{Sustainable Transport in Freiburg, Germany}

Since 1996, Freiburg has also improved regional suburban rail and regional bus services (from 2.7 billion to 3.4 billion seat kilometers annually), which are centered on Freiburg (Zweckverband Regio-Nahverkehn Freiburg (ZRF) 2008). Passenger km of regional rail use rose 6-fold between 1997 and 2006 and total public transport demand in the city of Freiburg and the surrounding region increased by 70\% (Regio-Verkehrsverbund (RVC) 2008a).

Light rail, regional rail, and bus services and timetables are fully integrated in Freiburg. Real-time information is provided by digital displays at rail stations, light rail stops, and key bus stops (City of Freiburg 2008f; ZRF 2003, 2008). Both light rail and bus services are faster and more reliable because of traffic signal priority, with lights turning green for oncoming trains and buses at key intersections.

These policies were complemented with an attractively priced, unified ticketing system, which enables riders to use a single ticket for several trip segments and different types of service. In 1984, Freiburg's public transport system offered Germany's first monthly ticket transferable to other users-called the "environmental ticket" (Bratzel 1999; Hilliard 2006). In 1991, the geographic coverage of the "environmental ticket" was expanded to include the two adjacent counties (ZRF 2008). These monthly tickets have offered bargain fares for regular public transport users for unlimited travel within the entire region (Gutzmer 2006; RVF 2006). The percentage of public transport riders using monthly tickets rose from only 39\% in 1974 to $92 \%$ in 2006 (RVF 2006; RVG 2008d). The environmental ticket introduced in 1984 contributed to the $42 \%$ increase in ridership between 1984 and 1990. Similarly, the introduction of the regional ticket in 1991 helped increase public transport trips region-wide by 70\% between 1991 and 2007 (Gutzmer 2006; RVG 2008b).

Services, fares, and subsidies for the entire Freiburg region are coordinated by a regional public transport association (ZRF), which serves 625,000 residents in 75 towns. ZRF sets the overall public transport policy in the region and develops and updates the regional public transport plan for 187 different bus and rail operators, 90 different lines, and $3050 \mathrm{~km}$ of routes (RVG 2008e, 2008f; ZRF 2008). It is also responsible for receiving funding from federal, state and local governments and then distributing those funds among public transport operators to cover investment and operating expenses (RVF 2008).

In summary, Freiburg and its surrounding region significantly increased the quantity and quality of public transport services. A higher share of trips by public transport has increased its financial sustainability and reduced $\mathrm{CO}_{2}$ emissions. Since January 1, 2009, Freiburg's light rail system runs solely on electricity generated by wind, solar, and water power, thus further decreasing the carbon footprint of transport in Freiburg.

\subsection{Promoting Bicycling and Walking for Short Trips}

The total number of bike trips in Freiburg nearly tripled between 1976 and 2007: from 69,500 to 211,000 -almost one bike trip per inhabitant per day (City of Freiburg 2008f; Pucher and Clorer 1992; University of Dortmund 2001). Between 1982 and 1989, the share of trips by foot in Freiburg has fallen from 35\% in 1982 to $23 \%$, apparently due to an increase in trip distances and a shift from walking 


\section{R. Buehler and J. Pucher}

to cycling and public transport. Since 1990, however, the walk share has remained stable in Freiburg, while it has been declining in Germany as a whole.

The decline in walking in the 1980s may have resulted from the city's focus on cycling. Freiburg expanded its network of separate bike paths and lanes from only $29 \mathrm{~km}$ in 1972 to $160 \mathrm{~km}$ in 2007 (City of Freiburg 2008a; FitzRoy and Smith 1998). Together with $120 \mathrm{~km}$ of bike paths through forests and agricultural areas, $400 \mathrm{~km}$ of traffic calmed roads, and $2 \mathrm{~km}$ of bicycle streets, Freiburg's cycling facilities have been fully integrated into a $682 \mathrm{~km}$ bikeway network (City of Freiburg 2008a). Cyclists can ride on separate facilities and safe, lightly traveled streets between virtually any two points in the city.

The city has traffic-calmed almost all residential streets. In 2008, about $90 \%$ of Freiburgers lived on streets with speed limits of $30 \mathrm{~km} / \mathrm{hr}$ or less (City of Freiburg 2008f). Speed limits are even further reduced to $7 \mathrm{~km} / \mathrm{hr}$ in 177 home zoneswhere cyclists and pedestrians have priority over cars, as illustrated in Figure 6 (City of Freiburg 2008f, 2009a). Traffic calmed neighborhood streets and home zones encourage more cycling and walking and make them safer (Herrstedt 1992; Morrison, Petticrew, and Thomson 2003; Tolley 2003; Webster and Mackie 1996). Freiburg allows cyclists to use half of the city's 120 one-way streets in either direction, while motorists are restricted to one-thus shortening bike trips compared to car travel distances (City of Freiburg 2008a).

Over the past three decades, the city has been increasing the supply of bike parking, improving its quality, and integrating it with public transport stops. Between 1987 and 2009, the number of bike parking spaces in the city center almost tripled, rising from 2,200 to 6,040 (City of Freiburg 2008a, 2008f; Gutzmer 2006). There are now 1,678 bike parking spots at public transport bike and ride facilities. In addition, there is a major bike station at Freiburg's main train station offering secure, sheltered parking for 1,000 bikes (for $€ 1$ per day or $€ 10$ per month), bike rental, bike repair, travel advice, and bike shipment to other cities (City of Freiburg 2008a). Not only does the city provide bike parking directly, but it also requires bike parking in all new buildings with two or more apartments, as well as schools, universities and businesses (City of Freiburg 2008d).

Freiburg has encouraged walking primarily through the car-free zone in the center, traffic calming of residential streets, and compact new developments that generate short, walkable trips (City of Freiburg 2008b). Walking in Freiburg's pedestrianized old town has been thriving, with $69 \%$ of all trips on foot in 2007. The latest transport plan foresees a westward extension of the pedestrian zone by about $0.5 \mathrm{~km}$ toward the main train station (City of Freiburg 2008f). The city acknowledges that its policies so far have only succeeded in stabilizing overall walking levels. In the future, Freiburg plans to improve the connectivity and safety of its citywide pedestrian network and intends to establish more pedestrian friendly neighborhood centers.

\subsection{Restrictions on Car Use}

Many of the policies that promote public transport, bicycling, and walking involve restrictions on car use-such as car-free zones and traffic-calmed neighborhoods. Freiburg's official goal is to reduce car use as much as practical, but to selectively accommodate car trips that cannot be made by any other mode. Thus, 
the city combines disincentives to car use in the town center and residential neighborhoods with improvement of arterials that have been widened or altered in various ways to increase their carrying capacity (City of Freiburg 2008f; Gutzmer 2006).

Freiburg's parking policy is designed to make car use less convenient and more expensive. Parking garages are relegated to the periphery of the city center, thus forcing motorists to walk or take public transport to access their cars. In many residential neighborhoods, parking is reserved for residents only and requires a special permit. On-street parking in commercial areas of the city becomes more expensive with proximity to the center: $€ 2.20$ per hour in the innermost zone, $€ 1.60$ per hour in the intermediate zone, and $€ .60$ per hour in the outermost zone (City of Freiburg 2006, 2008f). Almost all on-street car parking is limited in duration to prevent long-term parking by commuters. Building codes have reduced parking requirements for cars in new residential developments at the same time they increased parking requirements for bikes (City of Freiburg 2008e).

\section{SEVEN LESSONS FOR IMPLEMENTING SUSTAINABLE TRANSPORT POLICIES}

Freiburg's success has depended to some extent on special circumstances. Thus, it would be inappropriate to assume that Freiburg's particular approach should be copied exactly for implementation elsewhere. Nevertheless, there are many aspects of Freiburg's sustainable transport and land use policies that could be adapted for use by cities in other countries. For each of the seven lessons listed below, we note examples of Freiburg-type policies already being implemented in some U.S. cities. These specific examples in the USA suggest the adaptability of Freiburg's approach for use elsewhere. Policies that are feasible in the extremely car-dominated USA are probably transferable to other car-dependent countries such as Australia and Canada-and even more transferable to Western European countries with more balanced transport systems.

\subsection{Implement Controversial Policies in Stages}

Freiburg implemented most of its policies in stages, often choosing projects everybody agreed upon first. For example, residential traffic calming was initially implemented in neighborhoods whose residents complained most about car travel. Successful implementation in one neighborhood encouraged other areas of the city to request traffic calming as well. Some American cities already use a similar approach of implementing controversial policies in stages. For example, in 2009, New York City closed Broadway for car traffic between Herald Square and Times Square to experiment with a pedestrian plaza. The city has plans to make the change permanent if the trial proves successful and wins public support (New York City Department of Transportation 2009; Sadik-Khan 2010).

\subsection{Plans Should be Flexible and Adaptable over Time to Changing Conditions}

Over the last 40 years, Freiburg phased and adjusted its policies and goals gradually over time. For example, the initial decision to stop abandoning the trolley system was made in the late 1960s. In the early 1970s, the city council approved the extension of the light rail system-which finally opened in 1983. Once the expansion had 


\section{R. Buehler and J. Pucher}

proven successful, more new light rail lines followed. This phased approach can be found in many American cities, such as the light rail extensions in Portland, Oregon or the planned second light rail line in Minneapolis, Minnesota-where the successful Hiawatha Line triggered public demand for a second light rail line connecting Minneapolis to St. Paul (Metropolitan Council 2009).

\subsection{Policies Must be Multi-Modal and Include Both Incentives and Disincentives}

Freiburg has simultaneously made public transport, cycling, and walking viable alternatives to the automobile, while increasing the cost of car travel. Improving quality and level of service of alternative modes of transport made car-restrictive measures politically acceptable. The problem with car-restrictive measures in car-dependent countries such as the USA is that individuals rely on the car for about $90 \%$ of their trips. Thus, car-restrictive measures are opposed by the vast majority of the population. Yet as cities improve their public transport systems, as well as conditions for walking and bicycling, that may gradually increase the political feasibility of restricting car use. For example, as bicycling in Portland, Oregon has increased six-fold between 1990-2008, the city has transformed car parking spaces into bike parking; converted residential roads into bicycling boulevards with traffic calming and low speed limits; reassigned car lanes to bike lanes; and changed traffic signals to prioritize bicycles and public transport (City of Portland 2007, 2009).

\subsection{Fully Integrate Transport and Land-Use Planning}

Policies promoting public transport, cycling, and walking rely on a settlement structure that keeps trip distances short and residences and workplaces within reach of public transport. There are already some successful examples in the USA. Arlington County, Virginia developed high density mixed use neighborhoods around stops of the Washington DC Metro (Transit Cooperative Research Program 2004). Portland, Oregon is another prominent example of coordinating transport and land-use planning in the USA. Indeed, there are striking similarities between Portland and Freiburg in the development of their light rail systems, the planning of land uses around rail stops, the restrictions on suburban sprawl, and the focus on strengthening the central city and neighborhood-based commercial centers (Abbott and Margheim 2008; Ozawa 2004; Song and Knaap 2004).

\subsection{Citizen Involvement Must be an Integral Part of Policy Development and Implementation}

Since the 1970s, citizen participation has been a key aspect of transport and land-use planning in Freiburg. For example, citizen groups worked with the city administration to redevelop Vauban into an environmentally friendly car-free neighborhood. Moreover, Freiburg's latest land-use plan has been developed with sustained input of 900 citizens. Citizen involvement and public discourse kept the environment and sustainability of the transport system in the news in Freiburg for decades. Over time, public opinion in Freiburg has become more and more supportive of sustainable policies (Bratzel 1999). Even politicians from the conservative party have accepted restrictions on car use and have promoted public transport, bicycling, and walking as alternatives. Once more Portland, Oregon is 


\section{Sustainable Transport in Freiburg, Germany}

probably the best example in the USA, with a history of extensive citizen participation in transport, land-use, and environmental planning. Public involvement has been institutionalized into Portland's transport planning process through a city-funded network of neighborhood associations. Virtually every transport project includes public meetings, citizen advisory boards, focus groups, surveys, and public hearings to ensure citizen participation at every stage (Abbott and Margheim 2008; City of Portland 2007; Ozawa 2004; Shandas and Messer 2008).

\subsection{Support From Higher Levels of Government is Crucial to Making Local Policies Work}

Starting in the 1970s, the German federal government reduced funding for highways and provided more flexible funds for improvements in local transport infrastructure-including public transport, walking and cycling. Similarly, the state of Baden-Wuerttemberg provided funds for the initial trial of Freiburg's flat rate monthly transit ticket. Federal government support for public transport, walking, and bicycling has increased sharply in the USA since the early 1990s (America Bikes 2006; Clarke 2003). Successive federal transport laws (i.e., ISTEA, TEA-21, and SAFETEA-LU) have strongly encouraged, or even required, state and local governments to promote alternatives to the car, coordinate land use with transport, consider the needs of persons with disabilities, and mitigate the environmental, energy, and safety problems of urban transport (USDOT 2004, 2009a; Weiner 2008). The federal transport law is currently being revised for renewal, but indications are that there will be even more emphasis on promoting sustainability. That includes improvements to motor vehicle technology as well as policies to encourage public transport, walking, and bicycling.

\subsection{Sustainable Transport Policies Must be Long Term, with Policies Sustained Over Time, for Lasting Impact}

Changes in the transport system and travel behavior take time. Freiburg started its journey towards more sustainable transport almost 40 years ago. For example, the initial expansion of the light rail system took over a decade. Thus, planners should curb their expectations for quick success. Clearly, some policies can be implemented quickly, but changes in travel behavior and a more sustainable transport system take much longer. No large American city can claim such a long track record of sustainable transport policies. Nevertheless, the experience of Portland, Oregon over the past decades suggests that successful policies there have been self-reinforcing, generating increasing public support and thus enabling even more sustainable policies in successive years (Abbott and Margheim 2008; City of Portland 2009; Ozawa 2004).

\section{CONGLUSIONS}

Admittedly, Freiburg is not a typical city. Even within Germany it is viewed as the most sustainable city, and that is a country that appears to have far more sustainable transport and land-use systems than the USA, Canada, or Australia. Thus, many readers might be tempted to dismiss the impressive example of Freiburg as being irrelevant to cities in more car-dependent countries. 


\section{R. Buehler and J. Pucher}

Yet even in the most car-dependent countries like the USA, Canada, and Australia, many cities have been implementing bits and pieces of the Freiburg policy package over recent decades. In cities throughout these three countries policies have increasingly promoted alternatives to the car: through improved public transport, bicycle paths and lanes, better sidewalks, traffic calming of residential neighborhoods, and pedestrian zones. The biggest difference is that American, Canadian, and Australian cities rarely implement measures that restrict car use by making it more costly, slower, and less convenient. Freiburg has implemented both carrot policies to encourage alternatives to the car and stick policies to discourage car use. While incentives for public transport, walking, and cycling can work alone to some extent, combining them with policy sticks for car use has the potential to amplify the beneficial impacts of policy carrots.

Changes in transport and land use policies towards limiting car use and promoting more sustainable modes of transport often face barriers such as political and public acceptability, institutional inertia, splintered institutional responsibilities and lack of cooperation, financial constraints, municipal competition, legislative limitations, and public resistance to culture and lifestyle changes (European Commission 2005; May 2008). As we have shown in this article, Freiburg also faced many barriers along its way to more sustainability, but it was able to overcome each of them through innovative approaches. Below we list a few specific examples of how Freiburg overcame financial, institutional, legislative, political, and acceptability barriers over time:

- In the early 1970 s local business leaders opposed the implementation of the downtown pedestrian zone-fearing a loss of customers and revenue. Local business opposition only subsided when citizens and the city government agreed to build parking garages at the edge of the proposed pedestrian zone, thus ensuring access for customers.

- In 1984, Freiburg's transit provider (VAG) opposed the introduction of a flat fare monthly public transport ticket-fearing declining revenues and financial disaster. To overcome that resistance, the state government provided financial guarantees during the initial implementation phase. Freiburg's city council then forced VAG to implement the ticket, which turned out to be a huge success. Today VAG covers $90 \%$ of its operating budget with fare revenues-making Freiburg's transit system among the most financially sustainable in Germany.

- Many residents were initially skeptical about traffic calming for neighborhoods. However, successful implementation in a few neighborhoods convinced doubtful citizens to demand traffic calming for their own neighborhood. The strategy has been so successful that $90 \%$ of neighborhoods are now traffic calmed at $30 \mathrm{~km} / \mathrm{hr}$ or less. Freiburgers can now apply online to suggest that their street become a home zone with car travel speeds of less than $7 \mathrm{~km} / \mathrm{h}$.

- In the 1990s, car-free living in Vauban could only be realized after the city had negotiated an exemption from state-wide minimum parking standards. The state government agreed to count parts of Vauban's recreational park land as space holder for automobile parking. This satisfies state requirements for parking space provisions and citizen demand for open space. 


\section{Sustainable Transport in Freiburg, Germany}

- Coordination with neighboring municipalities on land-use and transport planning has not always been easy. For example, many transit providers in the region only agreed to join the unified regional transit ticket after receiving an initial contract guaranteeing a certain amount of annual revenue. That protected the transit providers against financial risks of joining the regional transit authority.

Portland, Oregon probably is the best example of sustainable transport and land-use policies in the USA. Although it does not restrict car use nearly to the extent of Freiburg, it has pursued a well integrated program of improvements to public transport, walking, and cycling while promoting compact, mixed use development and discouraging car-dependent sprawl (Abbott and Margheim 2008; Ozawa 2004; Shandas and Messer 2008). Most studies deem Portland's policies a success (Abbott and Margheim 2008; Ozawa 2004). Trends in travel behavior also point towards increasing sustainability of the transport system. Between 1990 and 2008, the mode share of workers commuting by car, truck, or van fell from $78 \%$ to $69 \%$, while the share of bike and public transport commuters increased from $12 \%$ to over $18 \%$. The growth for bicycling is particularly impressive: the average number of daily bike commuters increased six-fold $(+586 \%)$ between 1990 and 2008. During the same time period, the average number of daily public transport commuters increased by $55 \%$ (U.S. Census Bureau 1990, 2009). Portland's success provides hope that other car-dependent cities in the USA and around the world can also become more sustainable.

\section{ACKNOWLEDGEMENTS}

The authors are indebted to Uwe Schade, Bernhard Gutzmer, Wulf Daseking (all City of Freiburg), Andreas Hildebrandt (VAG Freiburg), and Tobias Bernecker and Dagmar Glaser (State of Baden-Württemberg) who provided much of the information presented in this article. We would also like to thank Martin Wachs, Robert Noland, Dale Medearis, and Kris Wernstedt for their suggestions for improving earlier drafts of the article.

\section{REFERENCES}

Abbott C, Margheim J. 2008. Imagining Portland's urban growth boundary: Planning regulation as cultural icon. Journal of the American Planning Association 74(2):196-208.

Altshuler AA, Womack JP, Pucher J. 1979. The Urban Transportation System: Politics and Policy Innovation. Cambridge, MA: MIT Press.

America Bikes. 2006. SAFETEA-LU provisions for cycling and walking. Washington, D.C.: America Bikes.

American Public Transport Association. 2006. Transportation factbook. Washington, D.C.: American Public Transport Association.

Banister D. 2005. Unsustainable Transport: City Transport in the New Century. London and New York: Routledge.

Bassett D, Pucher J, Buehler R, Thompson D, Couter S. 2008. Walking, cycling, and obesity rates in Europe, North America and Australia. Journal of Physical Activity and Health $5(6): 795-814$. 


\section{R. Buehler and J. Pucher}

Beatley T. 2000. Green Urbanism: Learning from European Cities. Washington, D.C.: Island Press.

Blatter J. 1995. Möglichkeiten und Restriktionen für umweltorientierte Maßnahmen im Personennahverkehr - Analyse der Freiburger Verkehrspolitik (Opportunities and threats for environmental transport policy - analysis of Freiburg's transport policy). EURES discussion paper, dp-47.

BMVBS (Federal Ministry of Transport, Building and Urban Development). 1991-2008. Verkehr in Zahlen (German transport in figures). Berlin: German Federal Ministry of Transportation and Urban Development.

BMVBS. 1993. Law and practice of urban development in the Federal Republic of Germany. Bonn: German Federal Ministry of Transportation and Urban Development, Bundesamt fuer Bauwesen und Raumordnung.

BMVBS. 2000. Urban development and urban policy in Germany. Bonn: German Federal Ministry of Transportation and Urban Development, Bundesamt fuer Bauwesen und Raumordnung.

BMVBS. 2004. Mobilitaet in Deutschland (Mobility in Germany Survey). Bonn: German Federal Ministry of Transportation and Urban Development.

BMVBS. 2005a. Bericht fuer das Jahr 2005 ueber die Finanzhilfen des Bundes zur Verbesserung der Verkehrsverhaeltnisse der Gemeinden nach dem Gemeindeverkehrsfinanzierungsgesetz (Federal Subsidies for Local Transportation Projects). Berlin: German Federal Ministry of Transportation and Urban Development.

BMVBS. 2005b. Raumordnungsbericht 2005 (Federal land use report). Bonn: German Federal Ministry of Transportation and Urban Development.

Bratzel S. 1999. Conditions of success in sustainable urban transport policy - Policy change in 'relatively successful' European cities. Transport Reviews 19(2):177-190.

Bureau of Transportation Statistics. 2006. Energy efficiency of the vehicle fleet. Washington, D.C.: Bureau of Transportation Statistics, FHWA.

Buehler R, Pucher J, Kunert U. 2009. Making Transportation Sustainable: Insights from Germany. Washington, D.C.: The Brookings Institution.

Bundesregierung (German Federal Government). 1999. Bericht der Bundesregierung ueber den Oeffentlichen Nahverkehr in Deutschland nach Vollendung der Deutschen Einheit (Federal government report about public transport since German reunification). Berlin: German Federal Government.

CEMT (European Conference of Ministers of Transport). 2003. Implementing sustainable urban travel policies: National reviews. Paris: European Conference of Ministers of Transport.

Chaney S. 2008. Nature of the miracle years: Conservation in West Germany, 1945-1975. New York: Berghahn Books.

City of Freiburg. 2004. Zukunft Freiburg Flaechennutzungsplan 2020 (The future Freiburg land use plan). Freiburg: City of Freiburg.

City of Freiburg. 2005. Drucksache G-05/234 Klimakonzept (Freiburg climate change plan 2005). Freiburg: City of Freiburg.

City of Freiburg. 2006. Parkleitsystem in der Innenstadt (Parking in the city center). Available at http://www.bis.freiburg.de/1/109/10906/index.php

City of Freiburg. 2007a. Drucksache G-07/102 Klimakonzept (Freiburg climate change plan 2007). Freiburg: City of Freiburg.

City of Freiburg. 2007b. The new district of Freiburg-Rieselfeld: A case study of successful, sustainable urban development. Freiburg: City of Freiburg.

City of Freiburg. 2007c. Verkehrsentwicklungsplan 2020 (Transportation Planning in Freiburg). Freiburg: City of Freiburg. 


\section{Sustainable Transport in Freiburg, Germany}

City of Freiburg. 2008a. Bicycling in Freiburg. Available at http://www.freiburg.de/servlet/ $\mathrm{PB} / \mathrm{menu} / 1146345 \_11 /$ index.html

City of Freiburg. 2008b. Flaechennutzungsplan (Freiburg land use plan). Available at http://www.freiburg.de/servlet/PB/menu/1146328_11/index.html

City of Freiburg. 2008c. FRITZ Daten Online. Available at http://www.freiburg.de/servlet/ $\mathrm{PB} / \mathrm{menu} / 1156915 \_11 /$ index.html

City of Freiburg. 2008d. Richtzahlen zur Ermittlung der Fahrradabstellplaetze (Bike parking). Freiburg: City of Freiburg.

City of Freiburg. 2008e. Rieselfeld und Vauban Dokumentation 90ger Jahre (Rieselfeld and Vauban in the 1990s). Available at http://www.freiburg.de/servlet/PB/show/1196817/ Rieselfeld.pdf

City of Freiburg. 2008f. Verkehrsentwicklungsplan Endbericht 2008 (Transport plan 2008). Available at http://www.freiburg.de/servlet/PB/menu/1146894/index.html

City of Freiburg. 2009a. Freiburg: Green city. Available at http://www.freiburg.de/servlet/ $\mathrm{PB} / \mathrm{menu} / 1182949 \_11 /$ index.html

City of Freiburg. 2009b. FRITZ daten online. Available at http://www.freiburg.de/servlet/ $\mathrm{PB} / \mathrm{menu} / 1156915 \_11 /$ index.html

City of Portland. 2007. Portland, Oregon: Creating a world class bicycling city. Portland: Portland Office of Transportation and Bicycle Transportation Alliance.

City of Portland. 2009. Platinum bicycle master plan. Portland: City of Portland Office of Transportation.

Clarke A. 2003. Green modes and U.S. transport policy: TEA-21. In: Trolley R, (ed.), Sustainable Transport: Planning for Walking and Cycling in Urban Environments. Cambridge, UK: Woodhead Publishing, pp. 443-449.

Deka D. 2004. Social and environmental justice issues in urban transportation. In: Hanson S, Giuliano G, (eds.), Geography of Urban Transportation (3rd ed.). New York: Guilford, pp. 332-355.

DESTATIS (German Federal Statistics Office). 2003. EVS survey. Wiesbaden: DESTATIS.

Department of Energy. 2007. Transportation energy intensity indicators. Washington, D.C.: Department of Energy.

Downs A. 2004. Still Stuck in Traffic. Washington, D.C.: Brookings Institution Press.

European Commission. 2005. PLUME: Planning and urban mobility in Europe. Final Report. Brussels: European Commission.

European Commission. 2009. A European vision for sustainable transport. Brussels: European Commission.

Federal Highway Administration. 1990-2008. Highway statistics. Available at http:// www.fhwa.dot.gov/policy/ohim

Federal Highway Administration. 2006. Transportation statistics. Washington, D.C.: Federal Highway Administration.

FitzRoy F, Smith I. 1998. Public transport demand in Freiburg: Why did patronage double in a decade? Transport Policy 5:163-173.

Forum Vauban. 2009. Planning a sustainable community. Freiburg: Forum Vauban, e.V.

Fuerst D, Scholles F. 2003. Landes- und Regionalplanung Teil 1: Verwaltungswissenschaftliche Grundlagen (State and regional planning part 1: Administrative structures). Unpublished manuscript. Hannover: Institut fuer Landesplanung und Raumforschung (Institute of Spatial Planning and Regional Science).

Gutzmer B. 2006. Integrierte Stadt- und Verkehrsplanung in Freiburg im Breisgau (Integrated city and transport planning in Freiburg). Freiburg: City of Freiburg.

Hanson S, Giuliano G. 2004. Managing the auto. In: Hanson S, Giuliano G, (eds.), Geography of Urban Transportation (3rd ed.). New York: Guilford Press, pp. 382-402.

Harvey D. 1973. Social Justice and the City. London: Edward Arnold. 


\section{R. Buehler and J. Pucher}

Herrstedt L. 1992. Traffic-calming design-a speed management method: Danish experiences on environmentally adapted roads. Accident Analysis and Prevention 24:3-16.

Hilliard LM. 2006. Integrating the wheels in Freiburg, Germany. How the right plan, process, and politics can create a balanced transport system. Fehr and Peers Transportation Consultants.

Hirt S. 2007. The devil is in the definitions. Contrasting American and German approaches to zoning. Journal of the American Planning Association 73(4):436-450.

Hopwood D. 2007. Blueprint for sustainability? What lessons can we learn from Freiburg's inclusive approach to sustainable development? Refocus 8(3):54-57.

International Energy Agency. 2006. $\mathrm{CO}_{2}$ Emissions from fuel combustion: 1971-2004. Paris: International Energy Agency.

International Energy Agency. 2008. Energy prices and taxes. New York: International Energy Agency.

International Energy Agency. 2009. Energy oil statistics by country. Retrieved 12 December 2009 from http://www.iea.org/stats/prodresult.asp?PRODUCT=Oil

INKAR (Indikatoren, Karten und Graphiken zur Raum- und Stadtentwicklung). 2005. INKAR Database. Available at http://www.bbr.de

IRTAD (International Road Traffic and Accident Database). 2008. Selected Risk Values for the Year 2005. Available at http://cemt.org/IRTAD/IRTADPublic/we2.html

Koeberlein C. 1997. Kompendium der Verkehrspolitik (Compendium of Transport Policies). Munich: Oldenbourg Wissenschaftsverlag.

Kunzmann K. 2001. State planning: A German success story? International Planning Studies $6(2): 153-166$.

Levine J. 2006. Zoned out. Regulation, markets and choices in transportation and metropolitan land-use. Washington, D.C.: Resources for the Future.

May T. 2008. Changing behavior in passenger transport-strategies and barriers. Paris: International Transport Forum.

Metropolitan Council. 2009. Central corridor light rail transit. St. Paul: Twin Cities Metropolitan Council.

Morrison D, Petticrew H, Thomson H. 2003. What are the most effective ways of improving population health through transport interventions? Evidence from systematic reviews. Journal of Epidemiology and Community Health 57:327-333.

Nahverkehr Breisgau. 2008. Geschichte der Freiburger Strassenbahn und Omnibusse (History of light rail and buses in Freiburg). Available at http://www.nahverkehr-breisgau.de

National Highway Traffic Safety Administration. 2004. Traffic safety facts 2002. Available at http://www-nrd.nhtsa.dot.gov/pdf/nrd-30/NCSA/TSFAnn/TSF2002Final.pdf

New York City Department of Transportation. 2009. Broadway pilot program: Improving traffic flow and safety in the heart of midtown. New York: New York City Department of Transportation.

Oak Ridge National Laboratories. 2005. National household travel survey 2001. Version 2004. Oak Ridge, TN: U.S. Department of Energy. Available at http://nhts.ornl.gov.

Oak Ridge National Laboratories. 2008. Transportation energy data book. Oak Ridge, TN: U.S. Department of Energy.

Oeko Institut (Environmental Institute). 2007. Klimaschutzstrategie Freiburg (Freiburg's climate protection strategy). Freiburg: City of Freiburg.

Ozawa C. (ed.). 2004. The Portland Edge: Challenges and Successes in Growing Communities. Washington, D.C.: Island Press.

Polizeidirektion Freiburg (Police Directorate). 2005. Verkehrssicherheitsbericht 2005. (Traffic safety report).

Pucher J. 1998. Urban transport in Germany: Providing feasible alternatives to the car. Transport Reviews 18(4):285-310. 


\section{Sustainable Transport in Freiburg, Germany}

Pucher J, Clorer S. 1992. Taming the automobile in Germany. Transportation Quarterly 46(3):383-395.

Pucher J, Kurth S. 1995. Making transit irresistible: Lessons from Europe. Transportation Quarterly 49(1):117-128.

Regio Verkehrsverbund Freiburg (Regional public transport association). 2006. 15 Jahre Regiokarte (Region wide ticket: 15th anniversary). Freiburg: Regio-Verkehrsverbund Freiburg.

Regio Verkehrsverbund Freiburg. 2008. Einnahmen des Regio-Verkehrsverbund Freiburg und den Verlehrsunternehmen im RVF (Revenues of the public transport association of the Freiburg region and of its member public transport firms). Freiburg: Regio Verkehrsverbund Freiburg.

Regio Verbund Gesellschaft (Regional Public Transport Authority). 2008a. Entwicklung der Fahrgastzahlen 1990-2007 (Ridership trends 1990-2007). Freiburg: Regio Verbund Gesellschaft mbh.

Regio Verbund Gesellschaft. 2008b. Entwicklung der Fahrgastzahlen RVF (Regional trend in ridership). Freiburg: Regio Verbund Gesellschaft mbh.

Regio Verbund Gesellschaft. 2008c. Freiburger Verkehrs AG Entwicklung Fahrgaeste/Defizit 1980-2007 (Trends in passengers and deficits). Freiburg: Regio Verbund Gesellschaft mbh.

Regio Verbund Gesellschaft. 2008d. Gesamtstueckzahl Regiokarte von 1992-2007 (Trend in regional tickets 1992-2007). Freiburg: Regio Verbund Gesellschaft mbh.

Regio Verbund Gesellschaft. 2008e. Organisations- und Finanzbeziehungen (RVG organizational and financial structure). Freiburg Regio Verbund Gesellschaft mbh.

Regio Verbund Gesellschaft. 2008f. Verbandsaufgaben (Functions of the public transport association). Regio Verbund Gesellschaft mbh.

Rönnau HJ. 2004. Anforderungen and die Verkehrsfinanzierung - Strategien fuer neue Organisationsstrukturen und Finanzierungsinstrumente im ÖV (Strategies for new organizational and finance concepts for public transport). Paper presented at the SRL Halbjahrestagung.

Rönnau HJ, Schallaböck KO, Wolf R, Hüsing M. 2002. Finanzierung des oeffentlichen Nahverkehrs. Politische und wirtschaftliche Verantwortung trennen (Separating political and economic responsibilities for public transport finance). Der Staedtetag 12:9-14.

Ryan S, Thorgmorton J. 2003. Sustainable transportation and land development on the periphery: A case study of Freiburg, Germany and Chula Vista, California. Transportation Research Part D 8(1):37-52.

Sadik-Khan JI. 2010. Remaking Broadway for 2009. Paper Presented at the 89th Transportation Research Board Annual Meeting, Washington, D.C.

Schaefer K, Sclar E. 1980. Access for All: Transportation and Urban Growth. New York: Columbia University Press.

Schroeder EJ. 2009. Verkehrsentwicklung in der suedlichen Euroregion Oberrhein (Trends in travel demand in the southern European region along the Upper Rhine). Internationales Verkehrswesen 61(5):155-161.

Shandas V, Messer WB. 2008. Fostering green communities through civic engagement: Community-based environmental stewardship in the Portland area. Journal of the American Planning Association 74(4):408-418.

Socialdata. 2009. Mobility indicators of German cities. Munich: Socialdata.

Song Y, Knaap GJ. 2004. Measuring urban form: Is Portland winning the war on sprawl? Journal of the American Planning Association 70(2):210-225.

Sperling D, Cannon J. (eds.). 2009. Reducing Climate Impacts in the Transportation Sector. New York: Springer.

StatCan 2009. Place of work highlight tables: Employed labor force by mode of transportation. Ottawa, ON: Statistics Canada. 


\section{R. Buehler and J. Pucher}

State of Baden Wuerttemberg. 2008. Jahresfahrleistung im Strassenverkehr 1990, 2000 und 2005 - Stadtkreis Freibrug (Trend in annual public transport supply in Freiburg, 1990, 2000 and 2005). State of Baden Wuerttemberg.

Texas Transportation Institute. 2009. Urban mobility report. College Station, TX: TTI.

Tolley. 2003. Sustainable Transport: Planning for Walking and Cycling in Urban Environments. Cambridge, UK: Woodhead Publishing.

Transit Cooperative Research Program. 2004. Report 102: Transit oriented development in the United States-experiences, challanges, and prospects. Washington, D.C.: National Academies, Transportation Research Board.

Transportation Research Board. 1998. Consequences of the Interstate Highway System for Transit: Summary of Findings. Washington, D.C.: National Academy Press.

Transportation Research Board. 2009. Transportation Research Board Special Report 298: Driving and the built environment-the effects of compact development on motorized travel, energy ese, and $\mathrm{CO}_{2}$ emissions. Washington, D.C.: National Research Council of the National Academies, Transportation Research Board, Board on Energy and Environmental Systems.

Umweltbundesamt (UBA - Federal Environment Agency). 2005a. Vergleich der Schadstoffe missionen einzelner Verkehrstraeger (Comparison of emissions for different modes of transport). Dessau: Umweltbundesamt.

Umweltbundesamt (UBA - Federal Environment Agency). 2005b. Was Bringt Die Oekosteuer - Weniger Kraftstoffverbrauch Oder Tanktourismus (Results of the environmental tax reform). Dessau: Umweltbundesamt.

Umweltbundesamt (UBA - Federal Environment Agency). 2008. Politikszenarien fürden Klimaschutz IV (Political scenarios for climate protection). Available at http:/ / umweltdaten.de/publikationen/fpdf-l/3361.pdf

University of Dortmund. 2001. Gestaltungsraeume kommunaler Stadt- und Verkehsentwicklung (Local land use and transport planning). Dortmund: Universitaet Dortmund Fachgebiet Verkehrswesen.

U.S. Census Bureau. 1990. United states census 1990. Washington, D.C.: U.S. Department of Commerce, U.S. Census Bureau.

U.S. Census Bureau. 2009. American community survey. Washington, D.C.: U.S. Census Bureau.

U.S. Department of Labor. 2003. Consumer expenditure survey. Washington, D.C.: U.S. Bureau of Labor Statistics.

U.S. Department of Transportation. 2004. National bicycling and walking study: A ten-year status report. Washington, D.C.: U.S. Department of Transportation.

U.S. Department of Transportation. 2009a. HUD and DOT partnership: Sustainable communities. Washington, D.C.: U.S. Department of Transportation.

U.S. Department of Transportation. 2009b. Transportation and climate change clearinghouse. Washington, D.C.: U.S. Department of Transportation.

VDV (Association of German Transport Companies). 2008. VDV Jahresbericht 2007/2008 (Annual report 2007/2008). Available at http://www.vdv.de/publikationen/periodika.html

Vuchic V. 1999. Transportation for livable cities. New Brunswick, NJ: Center for Urban Policy Research.

Webster DC, Mackie AM. 1996. Review of traffic calming schemes in 20mph Zones. TRL Report 215. Crowthorne, UK: Transport Research Laboratory.

Weiner E. 2008. Urban transportation planning in the United States: History, policy, practice (3rd ed.). Westport, CT: Springer.

Wiegandt C. 2004. Mixed land use in Germany: Chances, benefits and constraints. Planning National Center for Smart Growth Research and Education, University of Maryland. 


\section{Sustainable Transport in Freiburg, Germany}

World Bank. 1996. Sustainable transport: Priorities for policy reform. Washington, D.C.: The World Bank.

World Health Organization. 2009. Global burden of disease. New York: World Health Organization.

ZRF (Zweckverband Regio-Nahverkehr Freiburg) (Regional public transport authority for the Freiburg region). 2003. Nahverkehrsplan 2004-2008 des ZRF (Public transport plan 2004-2008). Available at http://www.regioverbund.de/cms/Regioverbund/de/nav/zrf/ 1,300408,9677.html

ZRF (Zweckverband Regio-Nahverkehr Freiburg) (Regional public transport authority for the Freiburg region). 2008. Mobilitaet fuer die Region (Mobility for the region). Available at http://www.regio-verbund.de/projects/ 